\title{
Economic Planning during the Guided Democracy
}

\begin{abstract}
This chapter discusses the development of institutions of national planning during the Guided Democracy and how it increasingly integrated the state within this structure. Sukarno's Guided Democracy state wanted to reform the relationship between the old political elite, the new managerial elite and the wider Indonesian society. It wanted to do away with the centralization of power and authority within expert bodies and expand on the participation of both the old political elites and the wider Indonesian society in national, regional and local planning. The problems inherent in such a corporative planning structure came to a head with the failure of the Eight Year Plan of the Guided Democracy. This failure resulted in the recentralization of planning authority within the community of experts in a new planning body that would become central to New Order policy making in the future, the Bappenas. The integration of national, regional and local government into the institution of planning had resulted in the formation of new power relations that placed the military and expert planners in the center of state making policies. These forms of power relations had expanded the managerial state into the lower parts of the Indonesian state and thus opening the way for a more integrated managerial state that wield the ability to coordinate on a deeper level of society. The rise of regional planning coincided with the expansion of the army's role in regional power politics and administration.
\end{abstract}

\section{Keywords}

Depernas - Bappenas - eight year overall national planning - regional planning

This chapter discusses the development of the institution of national planning during the Guided Democracy. The question that the chapter aims to answer is: who was leading society? Was it the experts, whom Sukarno considered to have failed the nation in the 1950s? Or did another, more democratic form of leadership emerge? The BPN was changed into the Depernas. This chapter studies the experiment of 'social control' or 'social participation' and looks at why this experiment, in the form of the Depernas, failed, and how developments in the latter part of the Guided Democracy strengthened the role of the 
experts by giving them key positions in a new body, the Bappenas, which was central to economic policymaking during the New Order.

The Depernas was a forum that bypassed Parliament and combined the older planning board and political representation in one body, a form of social control through incorporation. The function of the 'democratic' Depernas was to represent the people in national planning. Thus, its decisions and consensus were to be acknowledged and the authority of the planning body would be self-evident. The introduction of the idea of social control, as exemplified by the Depernas, by the introduction of new institutions such as the company board (dewan perusahaan), and by ideas such as open management, represented a genuine attempt to implement changes. But it was one that would ultimately fail.

After the failure of the Depernas, the National Planning Body (Badan Perantjang Nasional, Bappenas) was created in 1963. This represented a correction to the corporatist experiment, allowing the 'experts' greater participation within the planning agency. It also included a political wing, the National Planning Consensus (Musjawarah Perentjanaan Nasional, Muppenas), which acted as the parliamentary wing of the Depernas. The Bappenas-Muppenas enabled the gradual re-infiltration of the 'expert' managerial class into planning. It created a planning structure that united the central and the regional executives. In this way, the answer to the problem that had plagued the 1950s - how to create coordination among the national executive in lieu of the Pamong Praja had seemingly emerged. The inherent tension between societal participation and expert leadership was to play out more forcefully in the economic policymaking of the period. The institutional development of planning, however, illustrated the rise of an executive class that owed its position to the efforts to implement national planning.

\section{1 \\ Transition from the BPN}

The BPN drew up Indonesia's first Five-Year Development Plan (1956-1960) in 1956. It was then submitted to Parliament but was not approved until 1958. In the meantime, many of the economic assumptions contained within it had changed. Aside from the enactment of a foreign investment bill, ${ }^{1}$ the plan failed to materialize. In 1958, the role of the BPN in national planning was replaced by

1 Submitted to parliament during the second Ali Cabinet in 1956, it was finally passed in 1959 . Bruce Glassburner, The Economy of Indonesia. Selected Readings (Ithaca: Cornell University Press, 1971), 9o. 
the newly created Depernas. The BPN had been a PSI-dominated bureau and when the social democrats lost political influence, the PKI succeeded in closing it down on charges of it being too 'capitalist'. ${ }^{2}$ The communists were very critical of the в РN's large-scale manufacturing projects, such as the Asahan Aluminium Mill. Ir. Djuanda Kartawidjaja, as prime minister, presided over the dissolution of his B PN power base, but he recovered his power by creating the Economic and Finance Bureau (Finek or sometimes called bureau number two), a prime-ministerial office with the task of assisting in economic matters. He appointed former B PN staff member Muljatno Sindhudarmoko as bureau chief, and Ali Budiardjo and Saubari as staff. ${ }^{3}$ This bureau, coupled with Djuanda's control of the FEUI, the Ministry of National Research (Kementerian Urusan Research Nasional) under Minister Sudjono Djuned Pusponegoro, ${ }^{4}$ and the Leknas, provided adequate protection for the core social scientists, enabling them to flourish both in research and in developing power relations.

The role of Djuanda during the early Guided Democracy period, from around 1957 to $1962 / 1963$, was perhaps as central as that of General Nasution. Although people like Sumitro Djojohadikusumo had left, the 'technocratic element' still existed at the core of both the government and the military. Taufik Abdullah recalled a conversation in which a famous Indonesianist said that 'people will realize later on how crucial Djuanda's role was in these critical years, and how much of a loss to the nation the sudden death of Djuanda was'. ${ }^{5}$ Djuanda died in 1963. Born on 14 January 1922 to Raden Kartawidjaja, a schoolteacher from the lower Sundanese nobility, Djuanda obtained a scholarship to study at the Bandung Technical College (Technische Hogeschool Bandoeng) in 1929, graduating as a civil engineer in 1933. He became a director of the Muhammadiyah teaching school in Batavia before getting a job as a civil servant with the Department of Water Control (waterstaat) in the province of West Java in 1939. Unlike Hatta or Sumitro, Djuanda thus never lived in Holland nor was he particularly active within the nationalist movement. ${ }^{6}$ With no affiliation to any particular party or ideology, Djuanda was a neutral option for Sukarno's right-hand man.

2 Robinson Pangaribuan, The Indonesian State Secretariat, 1945-1993 (Perth: Murdoch University, 1995), 15 .

3 Pangaribuan, The Indonesian State Secretariat, 16. Budiardjo was sympathetic to the PSI. Higgins and Higgins, Crisis of the Millstone, 87 .

4 Prior to his appointment as a minister, Pusponegoro was the rector of the Universitas Indonesia and dean of the Faculty of Medicine there.

5 Taufik Abdullah, 'Kata Pengantar', in Awaloeddin Djamin (ed.), Pahlawan Nasional. Ir. H. Djuanda. Negarawan, Administrator dan Teknokrat Utama (Jakarta: Kompas, 2001), xx.

6 Nanulaita, 'Ir. Haji Djuanda Kartawidjaja', 8-71. 
Rosihan Anwar called Djuanda a pioneer in the Indonesian technocracy, in that people like him 'have no specific ideological commitment, in fact they act and are apolitical. Their main function is to be a helper and to aid their political master. ${ }^{7}$ This was certainly not entirely true of the New Order technocrats, whose relationship with the military state was determined by their desire to promote a certain vision of the Indonesian economy. Quoting Hanna, Higgins stated that Sukarno's entourage was composed of sycophants, rogues, and houris. ${ }^{8}$ And although he wasn't 'political' in the usual sense, Djuanda was proheavy industry, supporting large projects such as the Jatiluhur electric plant, the Gresik cement plant, and the Krakatau steel mill. ${ }^{9}$

One of the most important components of the Guided Democracy state was the belief in the importance of centralizing the executive. The Pamong Praja corps, which had been slated to disappear under the decentralized regional governments, was revived by Sukarno in his presidential edict of $1959,{ }^{10}$ and this had the effect of recentralizing the executive." ${ }^{11}$ The Pamong Praja was to work alongside a territorial military structure that had also been expanded during the period. With the creation of a national planning body composed of representatives of working bodies (Karya groups), the fractious, decentralized, party-based society of Indonesian liberalism was replaced by an incorporated structure in which society would participate in national planning and in the greater economy through the application of open management systems. The structure of power would be centralized, allowing society and state to function as one organic whole.

\section{Institutional Development during the Guided Democracy}

On a general level, we can divide the Guided Democracy into two periods. The first covered 1957-1962 and represented an experimental period, in which various new institutions were set up within an environment that held an optimistic

Rosihan Anwar, 'Pelopor Teknokrat. Non-Stop Jadi Menteri', in Awaloeddin Djamin (ed.), Pahlawan Nasional. Ir. H. Djuanda Kartawidjaja. Negarawan, Administrator dan Teknokrat Utama (Jakarta: Kompas, 2001), 217-18.

8 Higgins and Higgins, Crisis of the Millstone, 122.

9 Mohammad Sadli, 'Pelopor Perencanaan Pembangunan Ekonomi', in Awaloeddin Djamin (ed.), Pahlawan Nasional. Ir. H. Djuanda Kartawidjaja. Negarawan, Administrator dan Teknokrat Utama (Jakarta: Kompas, 2001), 258-9.

10 J. D. Legge, Central Authority and Regional Autonomy in Indonesia: A Study of Local Administration, 1950-1960 (Ithaca: Cornell University Press, 1961), 21.

11 Legge, Central Authority and Regional Autonomy, 201-29. 
view of the future. It was a corporatist period in which participation in the planning body through Karya organizations was heralded as the foundation for a stable and efficient Indonesia. During this period, Sukarno's anti-expert feelings were at their height. The second period, $1962-1965$, was the period after the experiments had been conducted, when the mood shifted towards one of apathy and pessimism. The changes also saw Sukarno wielding increasing authority as well as a loss of power for Nasution. Interestingly, the latter period also saw the rise of Western-educated social scientists and communists in the executive and their increasing prominence in the discourse on the economy. There was also growing economic distress and a loss of control of the state, while simultaneously a series of new, executive institutions were established that were to become the institutional bedrock of the future New Order state. In short, it was a period rife with contradiction and conflict that witnessed the rise of a new generation of experts that was to exercise an increasing influence on the executive.

As Herbert Feith describes, Guided Democracy was both an initiative of the military and Sukarno, 'and they did so not as leaders and followers or as part of a single power group, but as two partners and followers, or as a part of a single power group, as two partners between whom relations were competitive as well as cooperative. ${ }^{12}$ In the early phase, starting around 1957 , Nasution used the martial law that was proclaimed after the dissolution of Ali Sastroamidjojo's Cabinet to push forward his institutional ideas. His authority as chief of staff of the army resulted in his command of the Central War Authority (Penguasa Perang Pusat, Peperpu), which controlled the Regional War Authority (Penguasa Perang Daerah, Peperda). Sukarno successfully wrested control of this double administration away from Nasution when he dissolved the Peperpu and established the Supreme War Authority (Penguasa Perang Tertinggi, Peperti), positioning himself as the head of both the civilian and the military administration. ${ }^{13}$ In December 1961, the Supreme Command for the Liberation of West Irian (Komando Tertinggi Pembebasan Irian Barat, коті) was created under Sukarno; this became the most important government agency, acting like a cabinet. ${ }^{14}$ The competitive atmosphere had resulted in the formation of institutions along similar lines by both the military and Sukarno. In many cases, the initiative was taken by Nasution and

12 Herbert Feith, 'The Dynamics of Guided Democracy', in Ruth McVey (ed.), Indonesia (New Haven: Hraf Press, 1964), 327.

13 Crouch, The Army and Politics in Indonesia, 47.

14 Penders and Sundhausen, Abdul Haris Nasution, 158. 
then followed by Sukarno. It was not until 1962, when Sukarno succeeded in undermining Nasution's position, that an expansion of executive authority took place under the presidential office, putting institutional authority in the hands of the president.

According to Daniel Lev, "The striking aspect of Guided Democracy as it developed after the restoration of the 1945 Constitution was that it contained many political but few institutional controls. For institutions were pulled apart and broken down but poorly reassembled. ${ }^{15}$ While there was an institutional breakdown, new organizations and institutions were created. While Sukarno's preoccupation with politics and the shoring up of his support base reduced the efficacy of these new institutional arrangements, it is important to realize that significant path-dependent changes were being wrought. The importance of the Guided Democracy experiment was in its impact on the establishment of Indonesia's state-society relations. The problems of perceived government inefficiency resulted in the creation of an 'experimental' state. In the words of Sukarno: 'If we admit that the Indonesian revolution is not yet over, we have to understand that we will have to confront continued renewal. Try this, if it doesn't work, try something else [...] if that doesn't work, then try again [...]. Revolution is a dynamic process. ${ }^{\prime 16}$ This experimental approach showed a belief in historical materialism and the dialectic of nature itself. As Engels said, 'the whole of nature has its existence in eternal coming into being and passing away, in ceaseless flux, unresting motion and change. ${ }^{17}$

Two important events heralded the rise of the Guided Democracy. The first was the expropriation of Dutch-owned enterprises and the subsequent forced repatriation of Dutch citizens from Indonesia. This resulted in the opening up of positions in newly nationalized corporations and, subsequently, the hasty expansion of management science to fill the void left by the departing Dutchmen. The second was the further implementation of the dual function of the military, which enabled greater participation by the military in both civilian and business management.

The figure above represents a simplified model of institutional development within the government during this period. The strategy can be divided into two: a macro strategy for state coordination and a micro strategy for the

15 Lev, The Transition to Guided Democracy, 286.

16 Sukarno, 'Don't Built a Façade on Sand', in Dewan Nasional (n.p.: Kementerian Penerangan RI, n.y.), 62 .

17 Friedrich Engels, The Dialectics of Nature, quoted by Roeslan Abdoelgani; see Abdoelgani, 'Tentang Ketegasan Sosialisme Indonesia I. Landjutan Kuliah Umum di Universitas Malang pada Tanggal 13 Februari 1961', ANRI, Roeslan Abdulgani, inv. no. 64. 


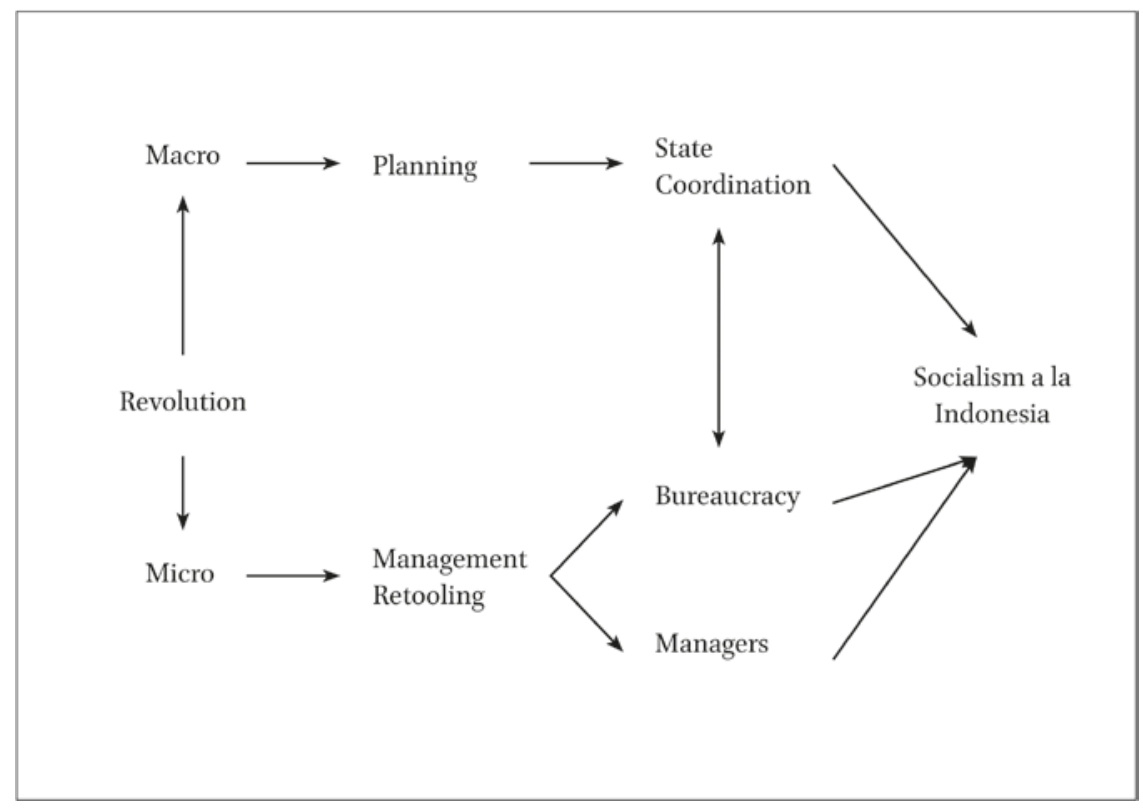

FIGURE 6 Institutional development under Guided Democracy

transformation of the individual civil servants. The macro strategy tried to resolve the 195os' problem regarding the inability of the state to implement concrete national coordination and planning. The micro strategy looked more deeply at the implementation of management science and the ideological efforts made to create a 'new Indonesian man' through the establishment of both state effectiveness and nation-building. State capability and nation-building became intertwined within an ideology that promoted the state's control as the end goal of the nation. This development was important because, although the Guided Democracy was a failure, it also cemented in place the kind of military-technocratic state that the New Order would become.

The Indonesian economy was restructured along corporatist lines when the government issued the Law on State Enterprise (Peraturan Pemerintah No. 16/ 1960) in April 196o. The law stipulated the creation of general management boards (badan pimpinan umum, or BPUs), which were given authority over the general management of, and staff functions for, particular industries: trading, mining and industry, sugar, rubber, agricultural products, and so on. The general management boards were created to replace the Nationalization Board (Badan Nasionalisasi, Banas) that was headed by Prime Minister Djuanda, the governor of the central bank, and eleven other ministers, who had managed 
the nationalization of the Dutch-owned companies. ${ }^{18}$ These BPUs were placed under the authority of the relevant ministries. Together they acted as a 'super management' board with the authority to intervene in day-to-day operations.

Back in 1957, the takeover of Dutch corporations had resulted in a group of military and civilian officers into the management rooms of corporations. On 10 December 1957, Central Military Ruler (Penguasa Militer Pusat) Nasution instructed all Regional War Authority (Penguasa Perang Daerah, Peperda) to take charge of Dutch corporations, many of which had already ended up in the hands of leftist trade unions. The creation of the Banas was a significant event as it brought policymaking for all types of nationalized enterprises under the central control of Prime Minister Djuanda, eleven other ministers, and the governor of Bank Indonesia. When a more permanent control machinery replaced the Banas, its staff was incorporated as a coordination board, ensuring continuity. ${ }^{19}$ Two important factors should be noted here. First, the appointment of Colonel Suprajogi as the head of the Banas and as minister of production coordination meant that the military gained a significant say in the organization. This included hiring people such as Colonel Soehardiman and other military managers to work at the Banas. Second, retaining the Banas under the Office of the Prime Minister ensured the continuity of significant parts of its policymaking, which was led by the expert elites of the planning body. As in economic planning, much of the policymaking was thus successfully retained under the authority of Prime Minister Djuanda.

Several months later, in March 1958, Nasution ordered the creation of the Central Body for the Management of Industrial and Mining Companies (Badan Pusat Penjelenggaraan Perusahaan-perusahaan Industri dan Tambang, or Bappit). The biggest shift in the management of state-owned companies took place in 196o with the issuing of a Government Regulation in Lieu of law (Peraturan Pemerintah Pengganti Undang-undang or Perpu).

Despite these manoeuvres, the presence of the military within these corporations, in the Bappit, and within the newly created BPUs remained, and, in fact, army men were present in practically all-important state institutions. Within the Bappit, three B PUs were created. ${ }^{20}$ The Depernas's discussion on the Corporatist Body of Private Business Owners (Badan Musyawarah Nasional, Bamunas) finally solved the issues surrounding the position of governmentowned corporations within the framework of socialism à la Indonesia. As in the area of national planning, experts like Mr Ali Budiardjo and managers such

\footnotetext{
18 Mackie, 'Indonesia's Government Estates', 341-2.

19 Mackie, 'Indonesia's Government Estates', 328.

20 Machines and Electricity, Chemistry, and Transportation.
} 
as Lieutenant Colonel Soekamto Sajidiman, who was the BPU director of the State Trading Corporation Juda Bhakti, visited countries including Yugoslavia and Czechoslovakia to study the role of the state, the market, and organizations like the Chamber of Commerce within the economies of these socialist states. ${ }^{21}$ There was interest in Yugoslavia's 'socialized enterprises' system, in which companies were not centrally nationalized but controlled by the workers through the formation of collectives. As with the regionalization of national planning, which the Depernas envisaged for later on, many experts also saw the need to decentralize ownership. ${ }^{22}$

Another important innovation in corporate management was the Company Council (Dewan Perusahaan). It was created on the assumption that workers having control over the management might result in a system of checks and balances that would reduce corruption. ${ }^{23}$ As Suprapto phrased it,

The capitalist oppression conducted through the hierarchical system, from the opperdirecteur in the Netherlands, via the directors, managers, representatives, and zetbaas in Indonesia must be revamped and changed into a democratic system that allows for the participation of workers in the management of the company, the planning of work, and planning itself. $^{24}$

There were two levels of council: the Management Board level and the company level. At the Management Board level, the council was composed of a representative from management, who served as the chairman, and a representative from a union or peasant organization connected to the company. If

21 Lieutenant Colonel Sajidiman specifically met with the Chamber of Commerce of Czechoslovakia in September 1961 to understand its role in the socialized economy, something which he envisaged the BPUs mimicking. Sajidiman, 'Perdjalanan ke Negeri Tjekoslowakia dalam rangka Tugas Pemerintah', Madjallah Perusahaan Negara, 1/11 (November 1961).

22 Mohammad Sadli, 'Masalah Perusahaan Negara di Indonesia. Laporan Symposium pada Latihan Pembangunan Ketatalaksanaan, Madjallah Perusahaan Negara, 2/18 (June 1962), 4 .

23 Mochammad Natzir, Dewan Perusahaan sesuai dengan UU No. 45 Prp. thn. 1960 (Makassar: Sedjahtera, 1963), 7 .

24 Suprapto, Dasar Pokok, Fungsi, Sifat2, 17. 'Sistim penindasan kapitalisme jang didjalankan dengan melalui hierarchie dari atas ke bawah, mulai dari opperdirectur di Negeri Belanda, direktur-direktur/manager-manager/vertegenwoordiger-vertegenwoordiger/ zetbaas-zetbaas di Indonesia harus dirombak dan diganti dengan sistim jang demokratis, jang memungkinkan kaum pekerdja turut serta dalam pimpinan perusahaan, turut merentjanakan pekerdjaan dan turut mengambil bagian dalam pelaksanaan rentjana.' 
the company was not in the agricultural sector, union representatives could replace peasant representatives. A union's membership had to equal 30 per cent of the total workforce of the company for it to be represented. An expert was appointed to be part of the council. At the company level, the ministers also had the right to appoint community leaders suggested by the local governor. The company board (dewan perusahaan) was a consultative body, offering recommendations for improving the environment of the companies in order to increase productivity. By the middle of 1964, there were twenty-one workersmanagement councils at the BPU level and 636 at the enterprise level; 60.5 per cent of the representatives were from labour unions, 13.5 per cent from the farmers' union, 24 per cent came from the management, and 2 per cent were experts. $^{25}$

Studies by Everett Hawkins have shown that there was a decrease in the number of labour disputes from 4,131, involving over five million workers, in 1957 , to 807 , involving over seven hundred thousand workers, in 1963. This was not because of a decrease in the number of grievances, but because labour disputes were transferred from the labour dispute bureau to the military's labour relations group (Badan Kerdja Sama Buruh-Militer, BKs-Bumil). ${ }^{26}$ Again, in accordance with Indonesian corporatist ideas, disputes and forms of decentralized decision-making were replaced by consensus within familial structures dominated by the executive, the military, or a combination of the two. The expansion of participation was met with hostility by some parts of the management, which often had a difficult relationship with aggressive unions. ${ }^{27}$

\section{3}

\section{Depernas}

The Depernas was entrusted to create not just an industrial or development plan, but an overall national plan 'to be built in accordance with Indonesian ideals'. ${ }^{28}$ It was an official, high government body, on the same level as Parliament and the Supreme Court. Sukarno wanted the Depernas to stand outside

25 Panglaykim, 'Indonesian State Enterprise and Worker-Management Councils (Dewan Perusahaan)', Asian Survey, 3/6 (June 1963), 285-8.

26 Everett Hawkins, 'Labor in Transition', in Ruth T. McVey, Indonesia (New Haven: Southeast Asia Studies, 1963), 248-71; Panglaykim, 'Worker-Management Councils in Indonesia', World Politics, $17 / 2$ (Jan. 1965), 243-55.

27 Panglaykim, 'Worker-Management Councils in Indonesia', 252.

28 Roeslan Abdulgani, 'The Lessons of Indonesia's Experience in Planning', in Politik dan Ilmu (Jakarta: B.P. Prapantja, 1962), 157 . 
and above the authority of the cabinet, although Djuanda was legitimately worried that this would make coordination difficult. Although he insisted in Parliament that the body should be under the authority of the cabinet, Sukarno's corporatist idea held sway. ${ }^{29}$ This decision was made through the National Council (Dewan Nasional). The council appointed the engineer Prof Herman C. Johannes of Gadjah Mada University to lead a nineteen-man commission to form the Depernas. The commission was composed of several intellectuals, including Gerrit Augustinus Siwabessy, an engineer; Tjan Tjoen Som, a Sinologist; and Raden Djokosoetono, a legal expert. On 8 October 1957, Johannes gave an exposition of the Depernas to the National Council, which approved it the following day.

Further discussion of the Depernas was deferred to the National Development Congress (Musyawarah Pembangunan Nasional, Munap), held on 2527 November 1957. The Munap was organized by the BPN. The BPN produced working papers, which were distributed and discussed by the various panels. Around four hundred delegates attended the congress from the government and the private sector. Regional civilian and military governors came with their advisers, along with members of the central government, Parliament, the Constituent Assembly (Dewan Nasional), and the National Council, and representatives of traders, industrialists, the banking sector, labourers, farmers, young people, women, reporters, veterans, artists, and religious leaders, all of whom were represented by their contemporary organizations. ${ }^{30}$

The corporatist nature of the congress was to be replicated in the Depernas, a prototype of which was first displayed by the National Council. This was part of the effort to create social control through social participation. ${ }^{31}$ These organizations traditionally had vertical ties to various parties, similar, according to Nasution, to the Dutch verzuiling structure. ${ }^{32}$ Djokosoetono

29 Lev, The Transition to Guided Democracy, 180.

30 Keng Po, 26 November 1957. Those attending included the SOBSI, the KвKI, and the RKS representing the labour organizations, while Majelis Perniagaan dan Perindustrian, the DEIP, the MII, the KENSI, and Perbana represented the economic sector. The BTI, the STII, and Petanu represented the agricultural sector, and the PWI, the IPPKN, and Ikatan Wartawan Ekonomi represented the reporters. Finally, Wakil Legiun Veteran and the MUVI stood for the veterans and the LEKRA and the BKMN for the artists.

31 Even at the end of the Guided Democracy, the creation of the Bamunas in 1965 was part of the effort to ensure 'social participation and social control'. Musjawarah Pusat Bamunas Ke-I. 19-2o Pebruari 1965 (Jakarta: Bamunas, 1965), 2.

32 A. H. Nasution, 'Mengabdi Bangsa Bersama Pak Djuanda', in Awaoeddin Djamin (ed.), Pahlawan Nasional. Ir. H. Djuanda Kartawidjaja. Negarawan, Administrator dan Teknokrat Utama (Jakarta: Kompas, 2001), 296-7. 
warned that corporatist states only existed in fascist and communist countries. ${ }^{33}$

The plan stressed the 'indigenous' nature of its creation, in comparison to the 195os' dependency on foreign experts. The Depernas was to be a testament to the capabilities of the non-professional. Roeslan reiterated this again in his speech in Malang: "The results of the Depernas in its basic principles are full of quality and value, in line with our revolution and the wishes of the people. This is not surprising. The character of its members determines the character of its results. ${ }^{34} \mathrm{He}$ added:

It is not too much to say that the members of the Depernas are the sons of revolution and the sons of the people. They are different from the previous planning and development boards, whch emphasized their members' intellectual expertise. Instead of these theorists, who had little contact with the common people, the Depernas focuses its membership on groups or Karya that have deep roots within and amidst society, without dispensing with the advice and opinion of experts. No less than 270 Indonesian experts in 12 fields of development, who have excellent qualifications and capabilities have been deployed and have had their opinions heard by the Depernas in order to perfect their work. ${ }^{35}$

On 16 July 1958, the Ministerial Council appointed Muhammad Yamin and Hanafi to formulate the Depernas bill. The Depernas was to devise, supervise,

33 Nasution, 'Mengabdi Bangsa Bersama Pak Djuanda', 297.

34 Abdulgani, 'Tentang Ketegasan Sosialisme Indonesia II. Landjutan Kuliah Umum di Universitas Malang pada Tanggal 13 Februari 1961', 68, in ANRI, Roeslan Abdulgani, inv. no. 641. 'Hasil-karya Depernas dibidang pengertian-pengertian jang pokok-pokok ini adalah hasil jang bermutu dan bernilai, tjotjok dengan tuntutan Revolusi kita dan Amanat Pederitaan Rakjat. Hal ini tidak mengherankan. Watak keangautaannja menentukkan watak-hasilnja.'

35 Abdulgani, 'Tentang Ketegasan Sosialisme Indonesia II', 68, ANRI, Roeslan Abdulgani, inv. no. 641. 'Karena itu tak berlebih-lebihan kiranja kalau dikatakan disini bahwa anggautaanggauta Depernas adalah putra-putra Revolusi dan putra-putra Rakjat. Berbeda dengan dewan-dewan perantjang dan pembangunan jang dulu-dulu, jang menitik-beratkan keangautaannja kepada para intelek-ahli dan intelek-expert, dan kepada ahli-ahli teori jang kurang berkontak dengan kehidupan Rakjat dan masjarakat, maka Depernas mengutamakan keanggautaannja untuk golongan-golongan karya jang berakar dimasjarakat dan ditengah-tengah rakjat, tanpa mengabaikan nasehat dan pendapat para ahli dan para expert. Tidak kurang dari 270 orang tenaga ahli Indonesia dalam 12 bidang pembangunan, jang bermutu tinggi dan berkapasiteit besar telah dikerahkan dan didengar pendapatnja oleh Depernas dalam penjempurnaan pekerdjaannja.' 
and evaluate an overall national plan. Its first duty was to create an Eight-Year Overall Development Plan. This was later expanded when, in January 1961, the president formed a working body to create an annual plan based on the EightYear Plan. On 30 June 1959, the Depernas decided to name Muhammad Yamin the minister-chairman of the Depernas. Within the Depernas, prominent individuals represented each province, usually the governor. The armed forces, as well as national businessmen and minority groups, were given seats in the body. This disparate collection of interests was convened over a period of ten months in order to create the Eight-Year Plan. Four plenary sessions were held based on the themes of basic necessities (sandang pangan), state constitution (kenegaraan), economy/finance, and society.

The master plan for Indonesia's first and only Eight-Year Plan was met with much scepticism. The plan was presented in the form of eight books, seventeen volumes, and 1,945 paragraphs. The symbolic nature of the arrangement of the plan was that it mirrored the date of 17 August 1945, Indonesian Independence Day. The Depernas was not clear on how its plans were to be superintended and reviewed. ${ }^{36}$ There was a struggle among the leadership over who was to carry out the plan, with Djuanda trying to entrust its control to a small, expert group of ministers and Chaerul Saleh trying to move it to his ministry. ${ }^{37}$ However, the Depernas lacked the institutional capability to carry out a national plan and became merely a council that collected departmental plans. It lacked coordinating and supervising capabilities. The plan also only included those projects that were to be financed by the central government. Regional-government and private-sector finance were not included. ${ }^{38}$ The plans themselves would eventually be given back to their respective ministries and departments and the problems inherent in them would result in their failure. The Eight-Year Plan was merely a collection of various projects without a unifying framework.

The plan was criticized externally, too. On a visit to Washington, DC in April 1961, Sukarno gave President Kennedy a copy of Indonesia's economic plan. Kennedy sent the plan to a team of experts from Yale University, who went on a twenty-four-day mission to Indonesia in August of the same year. The mission found deep flaws in the development programme. An expanded programme

$36 \quad$ Hasil Konferensi Kerdja Bappenas-Baperdep (Jakarta: Bappenas, 1964), 4.

37 J. A. C. Mackie, Problems of Indonesian Inflation (Ithaca: Modern Indonesia Project, 1967), 28.

38 Sutikno Slamet, 'Uraian Mengenai Pembiajaan Pembangunan Nasional, Pengawasan dan Penilaian', in Hasil Konferensi Kedja Bappenas/Baperdep-Bakopda (Jakarta: Bappenas, 1964), 102. 
of development was considered impossible 'until Indonesia makes greater progress in putting its house in order. ${ }^{39}$ One of the main conclusions was that American help should focus on the education and training of Indonesian managers and technicians, and proposed aid to the tune of $\$ 325^{-390}$ million. ${ }^{40}$ Without adequately skilled personnel, that money would not be spent but would only add to the rate of inflation. The investment required Rp 30 billion, or 13 per cent of Indonesian GDP in 1961 alone; for the entire eight years, it would have required Rp 240 billion, 50 per cent of which (that is, $\$ 270$ million) would have had to be paid in dollars. ${ }^{41}$ The Indonesian government ignored the report. ${ }^{42}$

In a report to the president, the minister of public works, engineer Sardjono Dipokusumo, reiterated that the plan made weak assumptions about project financing. The plan divided the projects into two: A projects and B projects. The A projects were 'proper' development projects, including those to achieve rice self-sufficiency and textile self-sufficiency, and to lay the foundations for heavy industry, such as the creation of steel and aluminium mills and petrochemical plants. All of this was to be financed by the B projects, which constituted 'low-hanging fruit', as they utilized Indonesia's rich resources. The Depernas mapped eight areas of Indonesian low-hanging fruit: petroleum, timber, fisheries, copra, rubber, tin, alumina, and tourism. While Indonesia had these resources in abundance, the Depernas failed to assess the capital and expertise needed to increase production in these sectors. For instance, the plan for Kalimantan timber was to export 37 million cubic metres of wood per year. However, the wood export volume of the entire world was only 40 million cubic metres. Such production would not only swamp the world's markets but would have required roads whose capital investment would have needed up to Rp 9o billion, twice the size of the 1961 national budget. ${ }^{43}$ Similar issues can be seen in the fisheries project, where calculations required Indonesia to invest in a fleet three times as large as the fleet belonging to the top fishing nation, Japan. As Dipokusumo reiterated in his conclusion: 'none of the plans above considers reality. None of them can be successfully conducted, perhaps some

39 Donald Humphrey et al., Indonesia. Perspectives and Proposals for United States Economic Aid (New Haven: Yale University Press, 1962), 16o.

40 Mahajani, Soviet and American Aid to Indonesia, 19.

41 Abdulgani, 'Tentang Ketegasan Sosialisme Indonesia II', 54, ANRI, Roeslan Abdulgani, inv. no. 641 .

42 Anwar, Sukarno, Tentara, PKI, 189. That \$3o billion would have had to be paid for through the national budget. Exports, in fact, decreased during the period. ANRI, Jakarta, Roeslan Abdulgani, inv. no. 88o.

Twice the national budget for 1961 . 
may be conducted on a small scale, but such a scale would never be justifiable as a source of meaningful development. ${ }^{\prime 4}$ Unfortunately, Yamin totally disregarded cabinet criticisms of the plans. ${ }^{45}$

Lack of data was cited as one of the main problems with the Eight-Year Plan. ${ }^{46}$ 'More often than not, the numbers do not match other data, or are not in accordance with reality. This situation had forced the Depernas to calculate its own numbers in important fields through the creation of special committees, such as the Population Committee (Komisi Populasi) and the National Income Committee (Komisi Pendapatan Nasional).47 They thus ignored the vital fact that the plan had no supporting organization to provide them with data. As a result, there were a lot of guesstimates. For instance, gross domestic product was calculated to be between Rp 163 billion and Rp 267 billion, depending on which of the seventeen volumes of the master plan was consulted; at the same time, per capita growth was assumed to be between o.1 and 5.6 per cent per year until 1969, depending on the population growth rate, which varied from 1 per cent to 3.6 percent per year in the various volumes. ${ }^{48}$ These figures were significantly different and thus provided different estimations of the developments in question. ${ }^{49}$

By 1962, the plan had essentially unravelled. Government investment in the plan had reached Rp 67.7 billion, or 41 per cent of Indonesia's GDP in 1960, using the Depernas's lower estimate. By the end of 1961, government revenue from these development projects had yielded just Rp 10.4 billion instead of the planned Rp 19 billion. In 1962, most of the Rp 40 billion needed to finance the plan had to come from the national budget because the projects had yielded a measly Rp 4.2 billion. The B projects yielded $\$ 5$ million, or Rp 225 million, from the Pan-American Oil Company, and Rp 20 million from tourism, out of a projected annual revenue of $\mathrm{Rp} 225$ million. The projected yields from forestry of Rp 295 million, fisheries of $\mathrm{Rp} 70$ million, copra of $\mathrm{Rp} 427$ million, and rubber of around $\mathrm{Rp} 1.8$ billion did not materialize due to either lack of

44 S. Dipokusumo, 'Masalah Pembiajaan Pembangunan Semesta, Rentjana Depernas', 2 September 196o, S.1417/9/6o, in ANRI, BAPEKAN, inv. no. 5 .

45 Guy Pauker, 'Indonesia's Eight Year Development Plan', Pacific Affairs, 34/2 (1961), 115.

46 Badan Perentjanaan Pembangunan Nasional (BAPPENAS). Peraturan-peraturan (Jakarta: Bappenas, 1964a), 8-9.

47 Badan Perentjanaan Pembangunan Nasional (BAPPENAS). Peraturan-peraturan (Jakarta: Bappenas, 1964a), 8-9.

48 Soerjadi, 'Sistim Ekonomi Terpimpin dibidang Moneter', speech given at the HSI Economic Seminar, 2o July 1963, 14-16.

49 For more on the history of national-income accounting, see W.H. Arndt and C. Ross, "The National Income Estimates', Bulletin of Indonesian Economic Studies, 6/3 (1970), 33-6o. 
investment or the inability to control the export market. Tin exports actually went down. ${ }^{50}$

There was a significant regrouping in 1962 . This resulted in national planning and many other institutes being placed under the office of the president, in a way similar to the centralized structure that existed during the parliamentary democracy. ${ }^{51}$ Economic deterioration and the failure of the Eight-Year Plan forced these changes and gave rise to a more significant role for experts within the government. Nasution, Sukarno's biggest rival, was effectively demoted by 'kicking him upward' to a technically higher post, but one with less authority. ${ }^{52}$ In the eyes of many, the appointment of Ahmad Yani as head of the army put the army more fully under the president's control. Roeslan Abdulgani was removed from the cabinet, which was a surprise to many. Djuanda kept his post, but by this time he was somewhat incapacitated by illness, having been diagnosed with heart problems in August 1961. Sukarno had also banished Sjahrir and his inner circle to East Java. ${ }^{53}$ On 17 October 1962, Muhammad Yamin died and was buried in West Sumatra. On 7 November 1963, Djuanda passed away.

A speech Roeslan Abdulgani gave in 1967, titled 'The Death of Djuanda: The Turning Point', emphasized the changes to the government after this period. According to Awaloeddin Djamin, the failure of the economic recovery (Dekon) was attributed to the absence of Djuanda, as influence passed to Soebandrio. ${ }^{4}$ This may be too simplistic an interpretation, as Soebandrio was instrumental in getting the nascent technocrats on board with the rehabilitation programme. It is also uncertain whether Sukarno would have listened to Djuanda's counsel and stopped the move towards foreign adventures in 1963. In any case, Sukarno took up the reins of power. In the meantime, Nasution vied for greater control and authority for his Ministry of Defence and thought that it would be good to imitate the Soviet system. He had collected papers

$5^{\circ} \quad$ Soerjadi, 'Sistim Ekonomi Terpimpin', 19-23.

$5^{1}$ By the end of the Guided Democracy, institutions under the presidential office would number 132, including sixty-eight departmental committees.

52 Nasution, Memenuhi Panggilan Tugas, Jilid v, 26; Penders and Sundhaussen, Abdul Haris Nasution, 140.

53 Anwar, Sukarno, Tentara, PKI, 123-7 and 128-30.

54 Awaloeddin Djamin (ed.), Pahlawan Nasional. Ir. H. Djuanda. Negarawan, Administrator dan Teknokrat Utama (Jakarta: Kompas, 2001), xii-xvii. 
on Soviet defence integration and given them to Djuanda's Committee of Six (Komite Enam). ${ }^{55}$ Instead, the result of the reorganization was greater control for the president through the котI, eliminating the authority of the Ministry of Defence. Sukarno also placed the intelligence agency (Badan Pusat Intelijen, BPI) within his office, under the authority of Soebandrio's Ministry of Foreign Affairs. ${ }^{56}$

The centralization of power under the presidential office led to a restructuring of national planning that opened the door for greater expert participation. This included continued involvement from foreign experts. Even during the reign of the Depernas, experts had been consulted regarding the creation of the Eight-Year Plan. In April 1960, in line with the government's request for technical assistance, the Americans had provided the expertise of the private economic consultants Bernard Bell and Oscar A. Ornati. ${ }^{57}$ A contingent of experts, including economists, tried to help with the plan's development by offering opinions to the members. For instance, in the case of agriculture, the Depernas relied on the reports of the FEUI's Research Institute for the Economy and Society (Lembaga Penjelidikan Ekonomi dan Masjarakat). ${ }^{58}$ From early 196o to 1964, the Indonesian government took on board the recommendations of the American consultancy company Griffenhagen-Kroeger, Inc. on the reorganization of the budgetary system; these followed on from the reports made by Karakachev, Kirkor, and other Indonesian experts. ${ }^{59}$ As part of the retooling, budgetary responsibility was moved from the Ministry of Finance to the presidential office, where it was placed under the authority of Prime Minister Djuanda. A major reason for placing it under the prime minister's authority was the concentration of experts at the Finek. This allowed effective fiscal control to be in the hands of the prime minister. The report from GriffenhagenKroeger concluded that the placement of the budget office under the authority of the prime minister would enable greater cooperation among the various government agencies and the executive in the presidential office. ${ }^{60}$

The period 1962-1965 saw even greater expansion of executive authority through the establishment of various new state bodies. Sukarno was also able

55 Nasution, Memenuhi Panggilan Tugas, Jilid v, 218-21.

56 Nasution, Memenuhi Panggilan Tugas, Jilid v, 218-21.

57 Pauker, 'Indonesia's Eight-Year Development Plan', 116.

58 Rantjangan Dasar UU Pembangunan Nasional-Semesta Berentjana Delapan Tahun: 19611969. Bidang Mental/Ruhani dan Penelitian, Buku ke III, Djilid vi: Pola Pendjelasan Bidang Pendidikan Tenaga Pembangunan (Jakarta: Dewan Perentjanaan Negara, 196o), 1689.

59 Tjokroamidjojo, 'Perkembangan Ilmu Administrasi Negara di Indonesia', 38 .

6o A Modern Budget System for Indonesia. Part A: Budget Organization (Jakarta: n.a., 1963), $1-5$. 
to take over the running of institutions that Nasution had created during his position as head of the army. By 1965, various bodies and institutions reported directly to the president. As head of state, he commanded seven institutions, including the State Secretariat and the cabinet. As the Great Leader of the Revolution (Pemimpin Besar Revolusi) he headed thirteen bodies. ${ }^{61}$ As the mandate holder of Parliament (Mandataris M PRS) he headed another twentythree agencies. ${ }^{62}$ Other state bodies directly under the authority of the president included the State Administrative Academy, the Central Statistical Board, the Office of Government Employees, and the Intelligence Office. Semi-private government bodies such as the Bamunas and the Indonesian Science Council (Madjelis Ilmu Pengetahuan Indonesia, MIPI) also reported to the president, as did international organizations headquartered in Indonesia such as the Ganefo (Games of the New Emerging Forces) Secretariat. Lastly, the president chaired sixty-eight bodies and inter-departmental committees, including the Economic and Development Council (Dewan Ekonomi Pembangunan, DEP) and the Council for Economy and Finance (Badan Ekonomi dan Keuangan, $\mathrm{BEK}$ ). In total, there were around 132 higher executive bodies by the end of the Guided Democracy. ${ }^{63}$

The creation of the Indonesian Science Council (M IPI) in 1956 provided a sanctuary for experts from the hostile political environment of the day. Research was alleged to be important to the Depernas, at least within its official publications, ${ }^{64}$ but it was not until 1962 that the government created the Department for National Research Affairs (Departemen Urusan Research Nasional), whose duty was 'to coordinate, stimulate and conduct research for the purpose of

61 Including the Front National, the Kotrar, the KотARI (Komando Operasi Berdikasi), the Kogam (Komando Ganjang Malaysia), the Kopedasan (Komando Pembangunan Daerah2 Perbatasan), the Lembaga Pembina Kesatuan Bangsa, the Komite Nasional Ganefo, the Lemhanas, et cetera.

62 Including the Conefo, the Committee for National Monuments and Istiqlal Mosque, the national television corporation, and the Jagorawi Highway Authority, among others.

63 Bintoro Tjokramidjojo, 'Masaalah jang Perlu Dipikirkan tentang Herordening Aparatur Negara Ditingkat Pusat', in Bintoro Tjokroamidjojo, Tulisan-tulisan Administrasi Pembangunan, 1966-1968 (Jakarta: Bappenas, 1971), 1-17.

64 M. Makagiansar and Widjojo Nitisastro (eds), Research di Indonesia, 1945-1965, Vol. IV: Bidang Sosial, Ekonomi dan Kebudajaan (Jakarta: Departemen Urusan Research Nasional, 1965), 13 . 
national development. ${ }^{65}$ The institutional environment for researchers and experts thus expanded significantly. As well as the Leknas and universities, other large economic organizations, such as the Bank of Indonesia, Bank Negara Indonesia, and the general management boards, also began to conduct their own research. ${ }^{66}$

The university was another important institution that expanded the influence of the expert. Higher education received significant attention from both Depernas's Eight-Year Plan and the government in general. The plan required the establishment of a Higher Education Ministry (Kementerian Pendidikan Tinggi) that was separate from the more general Ministry of Education and Culture, and this was achieved in 1961. The creation of the Department of Higher Education and Science in April 1961 and the regulation on universities aimed to integrate the universities into the development and revolution of the Guided Democracy. The universities formulated an ethical oath called the Tri Dharma, or three purposes (of higher education), whose third purpose specifically endorsed the role of higher education in societal development. This was interpreted as meaning that there would be greater state intervention, especially in such matters as the curriculum. A Conference of Similar Faculties (Pertemuan Antar Fakultas) took place, at which twelve types of faculties that taught across the country came together, resulting in the formation of the Expert Committee of Similar Faculties. This committee helped the department to evaluate the results of the conference in order to streamline the curricula of faculties throughout the nation. ${ }^{67}$

The government was committed to the formation of a higher-education institute for each province and the strengthening of the science and technology sector in the quest to industrialize. ${ }^{68}$ In 1962 , a series of inter-university and inter-faculty meetings was conducted in order to discuss the creation of a uniform national curriculum and standardized teaching methods. The Expert Committee on Uniform Faculties, which met from 20 to 22 December 1963,

65 Makagiansar and Nitisastro (eds), Research di Indonesia, 14. 'untuk mengkoordinir, menstimulir dan mengadakan research untuk kepentingan dan pembangunan Negara, baik dibidang ilmu-ilmu pengetahuan semesta alam, maupun dibidang ilmu-ilmu pengetahuan social dan kemanusiaan dengan memberikan prioritas kepada research dibidang produksi.'

66 Mohammad Sadli, '20 Tahun Perkembangan Ilmu Ekonomi di Indonesia', in Makagiansar and Nitisastro (eds), Research di Indonesia, 1945-1965, Vol. IV: Bidang Sosial, Ekonomi dan Kebudajaan (Jakarta: Departemen Urusan Research Nasional, 1965), 188.

67 Barli Halim, 'Ilmu Ekonomi Perusahaan', in Makagiansar and Nitisastro (eds), Research di Indonesia, 220-2.

Neff, Educational Planning in a National Development Context, 180. 
created a Ministry Ruling Concept for the curricula for all science faculties, which was to be confirmed in a government regulation at a later date. Many facets of the student's university learning experience were regulated by government decisions: the number of hours per semester, the percentage of time devoted to laboratory work (praktikum), the number of classes per semester, and so forth. ${ }^{69}$

The designation of feeder universities, whose duty was to provide teaching staff or training for faculty members of other universities, aimed to ensure uniformity. All feeder faculties were at either the University of Indonesia or Gadjah Mada University. ${ }^{70}$ All feeder faculties had affiliations with American universities. What is significant here is the fact that these American affiliations continued into the Guided Democracy period. The continuing elitist nature of this development was illustrated by a survey of Gadjah Mada University students in 1960, which showed that 84 per cent of students came from urban high schools and 6o per cent from just three major cities. ${ }^{71}$

In November 1962, an Inter-Economic Faculties Conference (Konperensi Antar Fakultas Ekonomi) was held to develop the economics curriculum with regard to Indonesian socialism. In order to determine exactly what counted as part of Indonesian socialist economics, especially in relation to the content of the curriculum, a series of conferences was held. The Third Congress of the Indonesian Economic Scholars Community (Ikatan Sardjana Ekonomi Indonesia) took place at Cipayung in December 196o, followed by the First Seminar on Agricultural Marketing in Bogor in December 1962, the Second MIPI Congress in Jakarta in October 1962, and the Grand Congress (Musjawarah Besar) of Economic Scholars and Experts in Jakarta in April $1964 .{ }^{72}$ There was an effort to introduce new economics literature from socialist countries; for instance, books written by Polish planning specialist Oscar Lange or socialist economists from the West, such as Paul Baran.

This literature formed the core of the new, 'Indonesianized' economics curriculum, and taxes on academic books were waived. There was thus an effort to develop an Indonesian science as opposed to merely importing American and

69 Rifai, Perkembangan Perguruan Tinggi, 64.

70 The Faculty of Medicine, University of Indonesia; the Institute of Agriculture Bogor, the Institute of Technology Bandung, and the Faculty of Agriculture and Forestry, Gadjah Mada University; the Faculty of Social and Political Science, Gadjah Mada University; the Faculty of Law, Gadjah Mada University; and, lastly, the Faculty of Economics, University of Indonesia. Rifai, Perkembangan Perguruan Tinggi, 68.

71 Joseph Fischer, 'Indonesia', in James S. Coleman, Education and Political Development (Princeton: Princeton University Press, 1965), 95.

72 Halim, 'Ilmu Ekonomi Perusahaan', 221. 
socialist books and ideas. This underscored both the increasingly pervasive nature of state intervention and the support that existed for the development of Indonesianized economics and other social sciences.

In 1960, MIPI had decided to expand its research through the creation of seven research institutes, among them the National Economic and Social Research Institute (Lembaga Ekonomi dan Sosial Nasional, Leknas). In March 1962, MIPI appointed an advisory committee headed by law expert Soediman Kartohadiprodjo, and composed of anthropologist Koentjaraningrat, economist Mohammad Sadli, sociologist Selo Soemardjan, international-politics and law expert M. Makagiansar, and agricultural specialist Kampto Utomo in order to establish Leknas. ${ }^{73}$ In March 1963, the Leknas was created. Immediately, the Ford Foundation provided Harvard advisers for the Leknas. ${ }^{74}$ Another important research organization, directly under the authority of the Faculty of Economics of UI, was the Economic and Social Research Institute. Prior to the formation of the Leknas, this institute played a greater role in economic research. The planning authorities were thus exposed to the ideas of both foreign and Indonesian economists. For instance, in October 1964, foreign experts from ECAFE in Bangkok were invited to teach at an advancement course in the field of planning engineering and methods. ${ }^{75}$

As older, Dutch-trained experts left their positions, were made redundant, or died, the field opened up to greater participation by American-trained experts. Older economists or managers, such as Sumitro Djojohadikusumo, Mohammad Hatta, Sjafruddin Prawiranegara, and Jusuf Wibisono, had, by now, been effectively sidelined. Some, like Djuanda Kartawidjaja and Muhammad Yamin, passed away in the early 196 os. $^{76}$ The communists' attack on Westerntrained experts and followers of Sumitro delineated the significant position these economists had held within the government. They had initially sought political protection from Prime Minister Djuanda and elites including Mohammad Hatta and Sjahrir. ${ }^{77}$ Later on, their position became more entrenched within the bureaucracy. In Mohammad Sadli's words:

73 Sadarjoen Siswomartojo, A Tentative Statement about the Set-Up, Nature and Purpose of the National Institute for Economic and Social Research of the Council for Sciences of Indonesia (Jakarta: Leknas, 1963), 4.

74 Joseph J. Stern, 'Indonesia-Harvard University: Lessons from a Long-Term Technical Assistance Project', Bulletin of Indonesian Economic Studies, 36/3 (December 2000), $113-25$.

75 Suharto, 'Pidato Penutup', in HasilKonferensi Kerjda Bappenas/Baperdep-Bakopda (Jakarta: Bappenas, 1964), 147.

76 Djuanda died in November 1963 and Muhammad Yamin in October 1962.

77 Herbert Feith, Soekarno-Militer dalam Demokrasi Terpimpin (Jakarta: Pustaka Sinar Harapan: 1995), 103. 
Because most economics graduates were still relatively young, by 1963 some of them had reached strategic, influential, or honourable positions, for instance, as aides to ministers, heads of directorates or offices, presidential directors or members of corporate organizations, heads of mass organizations or private organizations, or as professors, deans, or vice rectors at universities. The elevation of economists to the position of ministers or university rectors only became a phenomenon in 1964 and 1965. In general, these latter years began to see the start of the rise of economists to higher levels in society and the bureaucracy. ${ }^{78}$

Even so, competent experts and technocrats were 'dispersed throughout several departments and isolated from any central point of authority. ${ }^{\prime 9}$

The rise of this technically competent generation was, according to Feith, significant in understanding the continued promotion of revolution by the older generation. 'If the government were to speak less and less of the need for revolution and instead to declare economic development as the principle challenge of the present period', the top political leaders and heads of government enterprises 'would soon have their positions contested in the name of the government's ideology by others who could claim greater technical competence'. ${ }^{80}$ The contenders for these posts were either old administrators who had lost their jobs or up-and-coming university graduates with their formal education and bitter experience of having their career paths blocked by the current elite. ${ }^{81}$ In turn, the communists attacked the economists by using revolutionary rhetoric. According to Aidit, these experts were not showing their true colours but were secretly undermining the revolution: 'These cynics apparently obtain their energy and inspiration from the poisonous materials in the bulletins and periodical pamphlets spread by Sumitro and his agents within government offices and other parts of our government and economic

78 Sadli, '20 Tahun Perkembangan Ilmu Ekonomi di Indonesia', 184. 'oleh karena kebanjakan sardjana ekonomi relatip masih muda maka baru sedjak tahun 1963 beberapa diantara mereka mulai menduduki fungsiz jang strategis, berpengaruh atau jang terhormat, seperti misalnja pembantu2 menteri, kepala2 direktorat atau djawatan, presiden direktur atau anggauta direksi perusahaan besar, anggauta pimpinan ormas2, organisasi swasta, guru besar, dekan dan pembantu2 rektor universitas. Dipegangnja beberapa kedudukan menteri dan rector universitas oleh sardjana ekonomi baru mendjadi gedjala tahun 1964 dan 1965. Pada umumnja, tahun2 jang achir ini baru menundjukkan permulaan dari muntjulnja kaum sardjana ekonomi ditingkat2 atas masjarakat dan birokrasi.'

79 USAID, Human Resource Development, 13.

8o Quoted in Mackie, Problems of Indonesian Inflation, 52.

81 Feith, Sukarno-Militer dalam Demokrasi Terpimpin, 102-3. 
apparatuses. 82 The absence of communists within this structure was a significant factor. The party had its own educational system based on the People's University (Universitas Rakjat) and the Ali Archam institute, but 'the paucity of Marxist knowledge and of the scholarly output of its leaders' 83 further marginalized their position as outsiders regarding this institutional development.

The most serious attack on the entrenched position of the 'Sumitro followers' occurred in 1961, when Sukarno appointed Iwa Kusumasumantri, a radical nationalist with close ties to the Murba and the PKI, as minister of higher education and science (Menteri Pendidikan Tinggi dan Ilmu Pengetahuan, PTIP). Previously, higher education had been under the authority of the Ministry of Education and Culture, which assumed responsibility for all education in the country. It was headed by Minister Prijono, a Murba member who had received the Soviet peace prize. ${ }^{84}$ Iwa Kusumasumantri made several important changes to the curriculum and textbooks, especially in the field of the social sciences. His approval was necessary for students wishing to study abroad, which resulted in the end of Indonesian students being sent to the United States to study, and he asked students to report on signs of the teaching of liberalism in the universities. ${ }^{85}$ His high-handed dealings with faculties and members and his effort to introduce political goals created many enemies, both within and without the universities. In the cabinet reorganization of March 1962, Tojib Hadiwidjaja, a non-party, army-approved candidate, replaced him, which signalled the beginning of the long-term army control of the universities and campuses in much of twentieth-century Indonesia. As was the case with the creation of technocrats or army specialists, the left was never able to gain control of higher education. ${ }^{86}$

Research organizations such as the Leknas were institutionally connected with the leading universities, in particular the University of Indonesia. The

82 D. N. Aidit, Dekon dalam Udjian (Jakarta: Jajasan Pembaruan, 1963), 7. 'Kaum sinis ini ternjata pula mendapat angin dan inspirasi dari bahan-bahan ratjun berbentuk buletinbuletin atau stensilan-stensilan periodic jang pada saat ini diedarkan oleh pengchianat Sumitro dan agen-agennja dikalangan-kalangan pegawai perusahaan-perusahaan negara, kantor-kantor pemerintahan dan lain-lain bagian daripada aparatur pemerintahan dan ekonomi negeri kita.'

83 M. A. Jaspan, Aspects of Indonesian Political Sociology in the Late Sukarno Era (Nedlands: Centre for Asian Studies, 1967), 20-1.

84 Bresnan, At Home Abroad, 42.

85 Feith, Sukarno-Militer dalam Demokrasi Terpimpin, 84.

86 For more on the army-communist struggle over higher education, see Thomas R. Murray, 'Indonesian Education: Communist Strategies (1950-1965) and Government CounterStrategies (1966-1980)', Asian Survey, 21/3 (March 1981), 369-92. Also Suwignyo, 'The Breach in the Dike', 399-406. 
Leknas was not able to send its staff to the United States until 1963 and so had to rely on graduates from the FEUI for much of its research. A look at the activities of the Leknas in 1963 gives a glimpse of the kind of community and relations in existence in the middle of the Guided Democracy period. The Leknas did not have a ready expert staff of its own in its early years. In fact, its managing committee consisted of some of Indonesia's newest and brightest social scientists, fresh from postgraduate education in the United States; these included the economists Widjojo Nitisastro and Sarbini Sumawinata, the anthropologist Koentjaraningrat, and the sociologist Selo Soemardjan. They represented the 'Indonesian godfathers' of their respective sciences. The Leknas also employed consultants such as economists Mohammad Sadli, Everett Hawkins, and Kurt Martin, among others, and counterpart consultants including Ali Wardhana and Harun Zain. In June 1963, the Leknas signed a consultancy agreement with the Harvard Development Advisory Service.

The Leknas began sending its employees abroad to pursue postgraduate studies in the same year. Thee Kian Wie, Julian Luthan, and Lukman Siahaan were sent to study for master's degrees in economics at Wisconsin and Indiana Universities; T. S. S. Sutanto studied administration science at Pittsburgh; Tan Giok Lan and Harsja Bachtiar studied sociology at the University of California, Berkeley and Harvard, respectively; and D. M. Wattimena studied social psychology, also at the University of California, Berkeley. From October 1963, a regular weekly seminar was held at the Leknas, which was also attended by representatives from the Indonesian Science Council and the Department of National Research. Initially, the senior researchers, consultants, and counterpart consultants would give talks on actual and theoretical issues. The junior researchers would later contribute to the talks as well. The first workshop, held in April 1963, was on the issue of taxation and led by Sarbini Sumawinata. A second seminar, on the issue of managerial deconcentration in governmentowned enterprises, was led by Mohammad Sadli in July 1963. Both these themes supported the Dekon programme that had been announced in March of the same year. In September 1963, Kurt Martin led a seminar titled 'Inflation and Economic Growth'.

The relationship with Universitas Indonesia was certainly intimate, but the Leknas also reached out to other institutions. Everett Hawkins and Harun Zain conducted discussions and concluded agreements with Universitas Gadjah Mada and Universitas Padjadjaran, as well as cooperating with government departments, including the Department of Basic Industry and Mining (Departemen Industri Dasar dan Pertambangan). Many of the foreign relationships were with American or UN institutions, such as the Harvard Development Advisory Service, the Center for Research on Economic Development at Michigan 
University, UNESCo's Research Centre on Social and Economic Development in Southern Asia in New Delhi, and the Economic Commission for Asia and the Far East in Bangkok. However, in accordance with the shift in emphasis of the curriculum to better reflect Indonesia's socialist economy, there also were efforts to contact socialist social scientists, including two Russian economists, to discuss the problems of Indonesian economic growth in August 1963.

\section{$6 \quad$ Bappenas}

Efforts to recentralize planning resulted in the formation of the dichotomous Bappenas-Muppenas structure, which was inaugurated in December 1963. The Bappenas was created in December 1963 by a presidential decision that integrated the Depernas with the Bappenas, while at the same time reducing it to a body under the authority of the president, giving him yet further titles as coordinator of the Ministry for the Coordination of Development and day-today supervisor of the Ministry for Matters of National Development Planning (Urusan Perentjanaan Pembangunan Nasional, Uppenas). ${ }^{87}$ This reintegration under the executive was reiterated in Sukarno's May 1963 Ambeg Parama Arta speech, in which he outlined the country's economic policy (deklarasi ekonomi, Dekon), a terminology that, according to Lance Castles, ${ }^{88}$ was influenced by management science. Thus, the planning body was downgraded from a high government body to an adjunct of the presidential office, similar to the position of the BPN within the prime minister's office. The cabinet was also reorganized within a New Style Work Cabinet (Kabinet Kerdja Gaja Baru). ${ }^{89}$

In accordance with Presidential Decision No. 12/1963, the body wielded wide-ranging authority:

For the purpose of perfecting the National Overall Development Plan and the need to create detailed and derivative continuation, and in an effort to strengthen the integration of all government apparatuses, the Depernas in its former form and position has been integrated into the executive government apparatus or body, changing its structure and composition

87 For more on the structure of the Bappenas, see Hamzah Nasution, 'The Organization of the Planning Agency', Bappenas News Bulletin, 1/1 (1964), 30-5.

88 Lance Castles, 'Bureaucracy and Society in Indonesia: Paper for Discussion' (n.p.: n.n., n.y.).

89 Sukarno, Amanat PJм Presiden Republik Indonesia pada Sidang Pleno Terachir Depernas', in Badan Perentjanaan Pembangunan Nasional (Bappenas). Peraturan-Peraturan (Jakarta: Bappenas, 1964a), 4-7. 
in accordance with present development needs. After the Depernas completes its duties to create a Development Conception in accordance with our development principles as laid down within the Presidential Development Address in written and oral forms, we then need a more technical Development Planning and Supervision Apparatus to suit the level of growth of our Revolutionary Development. For this reason, the reforms and changes of the Depernas are focused on the creation of the National Development Planning Body or Bappenas, which will perfectly support the Executive Body in executing the planning and supervision of development throughout the country under the leadership of the Prime Minister assisted by a technical Minister. The Staff of the Bappenas will be composed of TECHNicaL EXPERTS in planning and development whose duty is to create detailed plans, in the form of yearly and long-term plans, as the perfect and continued implementation of our Development Conception. ${ }^{90}$

If the Depernas was the political organization that created the concept of national planning, the Bappenas-Muppenas acknowledged expert participation within the Bappenas, while giving a voice to political and social organizations. 'Our development planning apparatus has recently made significant strides. This is the culmination of historical development and experience over the last ten years, from the BPN to the Depernas and now to the Bappenas. ${ }^{91}$ The realization of the need for a good apparatus was apparent in many of the reports of the Muppenas/Bappenas. 'We know with clarity that our economic difficulties cannot be handled purely through formulating economic plans. As the gist of the recent Presidential political address (Amanat Politik) noted, however well formulated an economic plan is, its success is determined by the conditions of its apparatus. ${ }^{92}$

9o Quoted in Soerjadi, 'Sistim Ekonomi Terpimpin', speech given at the HSI Economic Seminar, 20 July 1963, 31-2. ANRI, Roeslan Abdulgani, inv. no. 1082. Capitalization according to the original.

91 Soeharto, 'Pidato Pembukaan oleh J. M. Menko Urusan Perentjanaan Pembangunan Nasional', in Hasil Konferensi Kerjda Bappenas/Baperdep-Bakopda (Jakarta: Bappenas, 1964), 3. 'Aparatur perentjanaan pembangunan kita telah mengalami kemadjuan jang pesat pada waktu achir2 ini. Hal ini adalah hasil perkembangan sedjarah dan pengalaman dalam pembangunan selama 10 tahun, dari Biro Perantjang Negara ke Depernas dan kini ke Bappenas.'

92 Kesimpulan-kesimpulan dan Kertas Kedja. Musjawarah Muppenas Ke III, 6, 'Kita mengetahui dengan djelas bahwa kesulitan2 ekonomi tidak bisa kita atasi hanja dengan perumusan2 tentang rentjana2 pembangunan ekonomi jang baik. Sebab sesuai dengan tjanang 
Although at the time the Bappenas was not fully under the control of the technocrats, as it was latterly in its role as the technocratic body par excellence for the New Order state, it assisted the rise of these new technocratic elites into various policymaking and expert-producing positions and represented an iconic change that signified the possible transition to a technocracy. The duties of the Bappenas included not only the creation of a national plan but also its supervision and implementation. There is no doubt that the Bappenas opened the doors to greater technocratic participation, as evidenced by the content of Sukarno's speech: 'The staff of the National Development Planning Board will be composed of technical experts in planning and development, whose duty is to write up detailed plans, on an annual and long-term basis... ${ }^{93}$

Three lessons had been learned from the failure of the Depernas. First, the lack of reliable data on the economy underscored the need to have credible research centres focused on collecting economic data, specifically statistical data concerning population growth, gross domestic product, and the domestic capital available for investment. ${ }^{94}$ Second, the failure spelt out the need to put the available expertise to better use. Third, it highlighted the failure of corporatist planning and stressed the need to 'recentralize' economic policymaking within a highly competent environment. The lack of oversight and implementation was also a major problem, which the Bappenas-Baperdep-Bakopda ${ }^{95}$ structure was intended to solve. ${ }^{96}$ The number of economic research bodies was expanded during the late Guided Democracy period. One of the most pertinent was the Central Statistical Board (в PS), a former colonial body, which, by the mid-195os, lacked the capability to generate economic data, including the national income index. Since 1955, the economist Sarbini Sumawinata, who had been trained by Nathan Keyfitz, had headed the вPs. ${ }^{97}$ However, despite this deficiency, economic research on Indonesia was forthcoming through the

P. J. M. Presiden dalam Amanat Politik beliau jang baru lalu maka bagaimanapun baiknja suatu rentjana ekonomi pelaksanaannja tergantung pada keadaan aparatur.'

93 Sukarno, Ambeg Parama Arta, 3o. 'Staf Badan Perentjanaan Pembangunan Nasional itu akan terdiri atas AHLI-AHLI TEHNIS perentjanaan dan pembangunan, jang bertugas membuat rentjana-rentjana terperintji, baik rentjana-tahunan maupun rentjanadjangka-pandjang, sebagai penjempurnaan dan pelaksanaan lebih landjut daripada Konsepsi Pembangunan kita.'

94 Slamet, 'Uraian Mengenai Pembiajaan Pembangunan Nasional', 97.

95 Baperda stands for Badan Perantjang Departemen, or Body for Departmental Planning; Bakopda means Badan Koordinasi Pembangunan Daerah, or Body for Regional Planning Coordination.

96 Hasil Konferensi Bappenas-Baperdep, 19-20.

97 Webster, Fire and the Full Moon, 88; Sumawinata, 'Recollections of My Career', 45-8. Progress was slow, but the first post-colonial population census was published in 1960 . 
FEUI. Moreover, steady cooperation with American universities and support from the Ford Foundation was allowing more Indonesians to study at US universities.

The main thrust of the Bappenas plan was to integrate the regions and the centre within one organizational authority. This was made possible in the early 1960s as the regional rebellions had been suppressed. ${ }^{98}$ By 1962, Sumatra was back under the control of the central government. The rehabilitation process became part of the discussion on the application of socialist models for institutionalized development. For instance, surveys of the various planning agencies in communist countries were made by Panglaykim and Hazil. ${ }^{99}$ Special interest was shown in the Soviet Planning model that had been introduced by Premier Khrushchev in the UssR's sixth Five-Year Plan (1956-196o) because of its decentralized and regional character. The Soviet's central-regional or Gosplan-Sovnarkhoze planning caught the fancy of the Indonesian government. The Gosplan or the Soviet state planning commission was quite similar in structure to the Depernas/Bappenas, while the 107 Sovnarkhozies were regional economic councils that had been introduced in the sixth Five-Year Plan as part of Khrushchev's decentralization plan. Khrushchev had called for a comprehensive plan that focused on creating greater efficiency and managerial leadership in order to give the republics, the ministries, and the administrators of productive enterprises greater responsibility.

Ideas regarding the development of a central-regional planning body that could function independently and serve to fine-tune the planning process were increasingly accepted. Earlier plans for regional planning bodies had been seen as contradicting the corporatist format that organized everyone within a unified and centralized body. It was argued that the regions were given plenty of representation within the Depernas and so regional planning bodies were not deemed necessary: "The government is of the opinion that there are already enough members sitting in the National Planning Council in the capital of Jakarta who are able to bring forward the development problems of first level regions of local autonomy.'100 It is possible that the government was now more assured of the docility of the regions after Jakarta's successful clampdown, and was thus more willing to provide the regions with institutions that had previously been seen as increasing the degree of independence from the centre.

98 Pauker, The Indonesian Doctrine of Territorial Warfare, vi.

99 Panglaykim and Hazil, Struktur Management dan Organisasi.

100 J. E. Ismael, 'Some Institutional Aspects in National and Regional Development', Ekonomi dan Keuangan Indonesia, 16/4 (October/November/December 1963), 25. 
An Economic and Social Research Institute survey conducted between October 1961 and February 1962 affirmed major problems of coordination. J. E. Ismael wrote, '[F]or instance, the Public Works and Power Service of some regions does not know whether the road repairs executed are part of the routine plan of their department or whether they are now included as one of the projects of the Plan. Thus, it becomes obvious that there is no coordination and communication both between the Departments and Local Governments and between the Departments at the Centre and the Services in the region. ${ }^{101}$ He implied that few of the coordination issues that had haunted the 195 os had ever been resolved. It was within this spirit of creating true coordination that the need for a regional approach was seen as essential. What was envisaged was an integrated regional development plan, as a more perfect alternative to the national overall development plan. Its implementation was to realize the old dream of integrating Indonesia's central and regional governments into one organization for the purpose of development.

\section{Structure and Organization}

The Bappenas was controlled by a secretariat composed of deputies (wakil menteri) from the Ministries of General Affairs (Urusan Umum), Planning (Urusan Perentjanaan), and Evaluation (Urusan Penilaian). At a lower level, eight bureaux were assigned to plan, supervise, and evaluate projects in their respective fields. ${ }^{102}$ These bureaux had functions that were similar to those of both the BPN and the Finek. The reports of the bureaux would then be used by the president as progress reports for Parliament (Majelis Permusjawaratan Rakjat Sementara, MPRS). As well as the Bappenas, there were also six permanent committees (komisi tetap) on rules and regulations, ${ }^{103}$ statistics, ${ }^{104}$ development surveillance and evaluation, ${ }^{105}$ natural resources, ${ }^{106}$ development

\footnotetext{
101 Ismael, 'Some Institutional Aspects', 25.

102 The bureaux were: management of the revolutionary soul, finance, development, distribution, domestic and legal affairs, defence and security, welfare, and international organizations and relations.

103 Peraturan Presiden Republik Indonesia No. 6 tahun 1964 tentang Panitia Negara Bappenas Urusan Tatatjara dan Peraturan.

104 Peraturan Presiden Republik Indonesia No. 7 tahun 1964 tentang Panitia Negara Bappenas Urusan Statistik.

105 Peraturan Presiden Republik Indonesia No. 8 tahun 1964 tentang Pengawasan dan Penilaian Pembangunan.

106 Peraturan Presiden Republik Indonesia No. 9 tahun 1964 tentang Panitia Negara Bappenas Urusan Sumber-sumber Alam.
} 
funding, ${ }^{107}$ manpower planning, ${ }^{108}$ and standardization and normalization. ${ }^{109}$ These committees were composed of experts from within and without the Bappenas and from the government and private sectors. They provided memoranda, consultation, and ideas to the UPPENAS, which oversaw the Bappenas. The last organization was the Muppenas, run by the deputy head of the Bappenas and head (pimpinan harian) of the Bappenas. It was composed of members of the Parliamentary Leadership Board (Badan Pembantu Pimpinan, MPRs) and provincial governors. The Muppenas was an advisory body, meant to provide advice and ideas for planning and development. What was thus envisaged was that the Bappenas would be an executive body with expertise committees forming permanent committees, with parliamentary and regional oversight provided by the Muppenas. This represented the central planning structure of the Republic. This central body had links with both regional and departmental planning. ${ }^{110}$

The planning process of the Bappenas was to be as follows: it would design a development policy, which would then be given a hearing by the Muppenas. After consulting the Muppenas, the plan would then be proposed to the president. The formulation of the plan required the help of two organizations: the Baperdep and Bamunas. The Baperdep would collect ideas and proposals from various departments and, through their respective ministers, convey them to the Bappenas. The Bamunas would conduct a similar process in the private sector. With regard to budgetary matters, a team comprising the Indonesian Development Bank (Bank Pembangunan Indonesia, Bapindo), the Department of Budgetary Affairs (Departemen $\mathrm{P}_{3}$ Urusan Anggaran), and the Bank of Indonesia would provide assistance with creating the budget. The Bappenas and the Bapindo would then be assigned to oversee budget implementation. The Bappenas would also evaluate the implementation of projects and write a development overview (ichtisar pelaksanaan pembangunan). The Baperdep and the Bakopda were obligated to provide their annual plans to the Bappenas. In order to create a better working environment and coordination, various conferences were held between the Bappenas and the other bodies in order

107 Peraturan Presiden Republik Indonesia No. 10 tahun 1964 tentang Panitia Negara Bappenas Urusan Sumber-sumber Pembiajaan.

108 Peraturan Presiden Republik Indonesia No. 11 tahun 1964 tentang Panitia Negara Bappenas Urusan Perentjanaan Tenaga Pembangunan.

109 Peraturan Presiden Republik Indonesia No. 12 tahun 1964 tentang Panitia Negara Bappenas Urusan Standardisasi dan Normalisasi.

110 Hasil Konferensi Kerdja Bappenas-Baperdep, 21-3. 
to synchronize their views. ${ }^{111}$ The Bappenas also laid on planning courses, for instance, in November 1964, in collaboration with the Asian Institute for Economic Development Planning. ${ }^{112}$

\section{8}

\section{Conclusion}

The implementation of national planning was initially predicated on the naïve and optimistic view that 'non-experts' could design and implement national plans. The failure of this intention and the economic deterioration resulted in a significant revamping of the executive in 1962. At the same time, newly trained experts began to pour into Indonesia, especially from American higher education. Their influence in various departments and higher learning/research institutes began to be significant by 1963 . The reforms initiated by Sukarno expanded the executive. The failure of the Depernas resulted in calls for the greater participation of the new generation of experts. Thus, on a national planning and bureaucratic level, there was a process of technocratic development. As we will see in Chapter 6, the rise of this new generation would be contested by the communists, who were also growing in power. The creation of the Bappenas was a significant development, for this body would play an important role during the New Order. There are obvious differences between the body established under the Guided Democracy and the one that existed during the New Order, which by then had become highly technocratic, but the structural shift that created this body represented an important institutional development that laid one of the foundations for the rise of the technocracy.

In the early 196os, efforts were made to use the social sciences, especially scientific management, to understand the problems of the Indonesian bureaucracy and to implement measures to create more efficient managers and bureaucrats. These measures were implemented on what I have termed the 'micro level', as opposed to the 'macro level', of national planning. The expansion of management education and the implementation of retooling and indoctrination courses constituted significant attempts to deal with the problems at the micro level. The next chapter will investigate this process and examine the extent to which the effort to implement knowledge of the social sciences affected the bureaucracy.

\footnotetext{
111 For instance, the Bappenas/Baperdep-Bakopda work conference held in September 1964. Hasil Konferensi Kerdja Bappenas/Baperdep-Bakopda Tanggal 22 s/d 24 September 1964 (Jakarta: Bappenas, 1964b).

112 Hasil Konferensi Kerdja Bappenas-Baperdep, 25.
} 